\title{
REVISION OF PIMELODENDRON (EUPHORBIACEAE) IN MALESIA
}

\author{
TUTIE DJARWANINGSIH \\ Herbarium Bogoriense, Puslit Biologi, Jalan Raya Juanda 22, P.O. Box 110, \\ Bogor 16122, Indonesia
}

SUMMARY

Pimelodendron comprises five species. Four species were already known (P. amboinicum, P. griffithianum, P. macrocarpum, P. zoanthogyne). One Sumatran species is to separate in the rest of Pimelodendron without naming it (Pimelodendron spec. nov.?). One name is excluded (P. dispersum = Actephila excelsa var. javanica), while $P$. naumannianum is regarded as a synonym of $P$. amboinicum.

Key words: Euphorbiaceae, Pimelodendron, Malesia.

\section{INTRODUCTION}

Pimelodendron Hassk. is a small genus (five species) in the Euphorbiaceae. Its distribution ranges from Peninsular Thailand to the Solomon Islands and tropical East Australia (Airy Shaw, 1977; Webster, 1994): Peninsular Thailand, Malay Peninsula, Sumatra, Borneo, Sulawesi, Lesser Sunda Islands, Moluccas, New Guinea, Solomon Islands, and NE Australia. There are three species distributed in Peninsular Malaysia, Sumatra, and Borneo; while one species ( $P$. amboinicum Hassk.) is distributed in Sulawesi, Lesser Sunda Islands, Moluccas, New Guinea, Solomon Islands, and NE Australia. Pimelodendron spec. nov.? is found in Sumatra.

Some species of this genus are economically important, they provide food, medicine, or varnish for local people. The wood of P. macrocarpum J.J. Sm. is used in house construction (Heyne, 1927). In Sumatra, the fruit of P. griffithianum (Müll.Arg.) Benth. is used for seasoning (Burkill, 1935). In eastern Malay Peninsula P. amboinicum furnishes edible seeds, which taste like hazelnuts; its bark is used as a purgative; the juice of the leaves, used in a mixture, cleans the mouths of children, and acts as a gentle purgative (adults can eat the leaves without purging); the latex serves as a varnish (Burkill, 1935). People in the Solomon Islands drink an infusion of the bark of P. amboinicum as a remedy for fever (Perry \& Judith, 1980).

Pimelodendron was established by Hasskarl (1855) based on a plant originally collected in the Moluccas and cultivated in the Bogor Botanical Garden (P.amboinicum); the type could not be traced. The original spelling is Pimelodendron. However, in later publications Hasskarl $(1857,1858)$ changed it to Pimeledendrum. The most commonly accepted and used spelling was introduced by Müller Argoviensis (1866) as Pimeleodendron (in his view a section of the genus Carumbium Reinw.(= Homalanthus)). According to the International Code of Botanical Nomenclature 1994 (Article 60.1; Greuter et al., 2000) the first spelling 'Pimelodendron' should be accepted as the correct 
spelling as already done by Airy Shaw (1971). Etymologically, the name Pimelodendron is derived from the Greek words 'pimelos', which means 'greasy/fat', and 'dendron' which means 'tree', thus the name refers to a tree with fatty seeds.

Webster (1994) and Radcliffe-Smith (2001) classified Pimelodendron in subfamily Euphorbioideae, tribe Stomatocalyceae, subtribe Stomatocalycinae because of the following characters: trees with abundant white latex; bracts (mainly) eglandular; sepals connate; staminate calyx 2-lipped; stamens free, 10-30; pollen sexine finely reticulateperforate; ovary 2-10-locular; styles undivided, short; fruits indehiscent; seeds ecarunculate. The morphology of the staminate flowers (a 2-lipped calyx) of Pimelodendron resembles that of Homalanthus A. Juss., but Pimelodendron is not closely related to Homalanthus (Esser et al., 1997). Homalanthus is classified in the tribe Hippomaneae, subtribe Carumbiinae (Webster, 1994; Radcliffe-Smith, 2001), the tribe treated after the Stomatocalyceae.

Müller Argoviensis (1866) described the new genus Stomatocalyx with the single species $S$. griffithianus based on various specimens from Peninsular Malaysia and Borneo. Bentham (Bentham \& Hooker, 1880) transferred this species to Pimeleodendron, thereby making Stomatocalyx a synonym of Pimelodendron. Warburg (1894) described $P$. papuanum from New Guinea and Borneo, and P. borneense from Borneo. Elmer (1908) recognised a new species for the Philippines, P. dispersum. Pax \& Hoffmann (1912) excluded P. dispersum from Pimelodendron and considered it to be a Cleistanthus species. They classified the three remaining species in tribe Hippomaneae, subtribe Homalanthinae. In 1916 Merrill described one new species from Borneo (P. acuminatum), followed in 1924 by Pax \& Hoffmann with P. naumannianum from Timor (Lesser Sunda Islands) and Smith (1924) with P. macrocarpum and P.papaveroides (both from Sumatra) and P. zoanthogyne (Borneo). According to Smith (1924) P. papuanum is a synonym of $P$. amboinicum.

Whitmore (1972) recognised two species for Peninsular Malaysia, namely P. griffithianum and P. macrocarpum. Airy Shaw (1975) identified three species for Borneo: $P$. griffithianum, $P$. macrocarpum, and P. zoanthogyne. He considered all other West Malesian names, $P$. acuminatum, $P$. borneense, and $P$. papaveroides, to be synonyms of $P$. griffithianum. Airy Shaw (1975), like Smith, regarded P. papuanum as a synonym of P. amboinicum. Airy Shaw (1981) accepted two species for Sumatra: P. griffithianum and P. macrocarpum, and a single species for Sulawesi and the Moluccas: P. amboinicum (Airy Shaw, 1982).

This short history of Pimelodendron indicates that the species concept in Pimelodendron is still confusing. Moreover, up to now only island revisions were published for most Malesian Euphorbiaceae and no general overview exists. The island revisions, mainly by Airy Shaw, lack descriptions and often the keys are not sufficient for identification. Therefore, a revision of the widespread Pimelodendron was urgently called for.

In the present study five species of Pimelodendron are recognized, of which four have been described previously (P. amboinicum, P. griffithianum, P. macrocarpum, $P$. zoanthogyne) and one Sumatran species is separated from in the rest of Pimelodendron without naming it (Pimelodendron spec. nov.?). One name is excluded, P. dispersum, which is a synonym of Actephila excelsa (Dalzell) Müll.Arg. var. javanica (Miq.) Pax \& K. Hoffm. One new synonym is proposed by uniting P. naumannianum with P. amboinicum. 


\section{CHARACTERS}

\section{Leaves}

Most species have paired glands at the base of the leaf blade on the lower surface, only P. macrocarpum is an exception.

The petiole length ranges from 1-12.5 cm and is variable within species, but differ distinctly between species. The upper side of the petiole usually has transverse ridges when dry ( $P$. amboinicum, $P$. griffithianum, and $P$. zoanthogyne); the ridges are absent in P. macrocarpum and Pimelodendron spec. nov.?.

The leaf margin of $P$. griffithianum is serrulate with the tip apiculate (Fig. 1e) and the teeth 1-2.1 cm apart. Pimelodendron macrocarpum has mostly serrulate with the tip apiculate (Fig. 1e) or rarely serrate and the tip apiculate (Fig. 1b) leaf margins, with the teeth 1-2.5 cm apart. Leaves of $P$. amboinicum are (serrulate to) serrate and the tip apiculate (Fig. 1b); some collections from Sulawesi have deeply serrate margins with the teeth 2-3 $\mathrm{mm}$ long and the tip apiculate (Fig. 1a), distance between teeth $2-4 \mathrm{~cm}$. The leaf margin of Pimelodendron spec. nov.? is serrate with the teeth curved inwards and the tip apiculate (Fig. 1c, 1d), distance between teeth $0.7-1.5 \mathrm{~cm}$ long; while the leaves of $P$. zoanthogyne are serrate and the tip apiculate (Fig. 1b) or rarely serrulate with the tip apiculate and the teeth $1-3 \mathrm{~cm}$ apart.

The upper surface of the leaves of P. amboinicum is shining when fresh, but dull when dried; in P. macrocarpum the leaves remain shining even when dry.
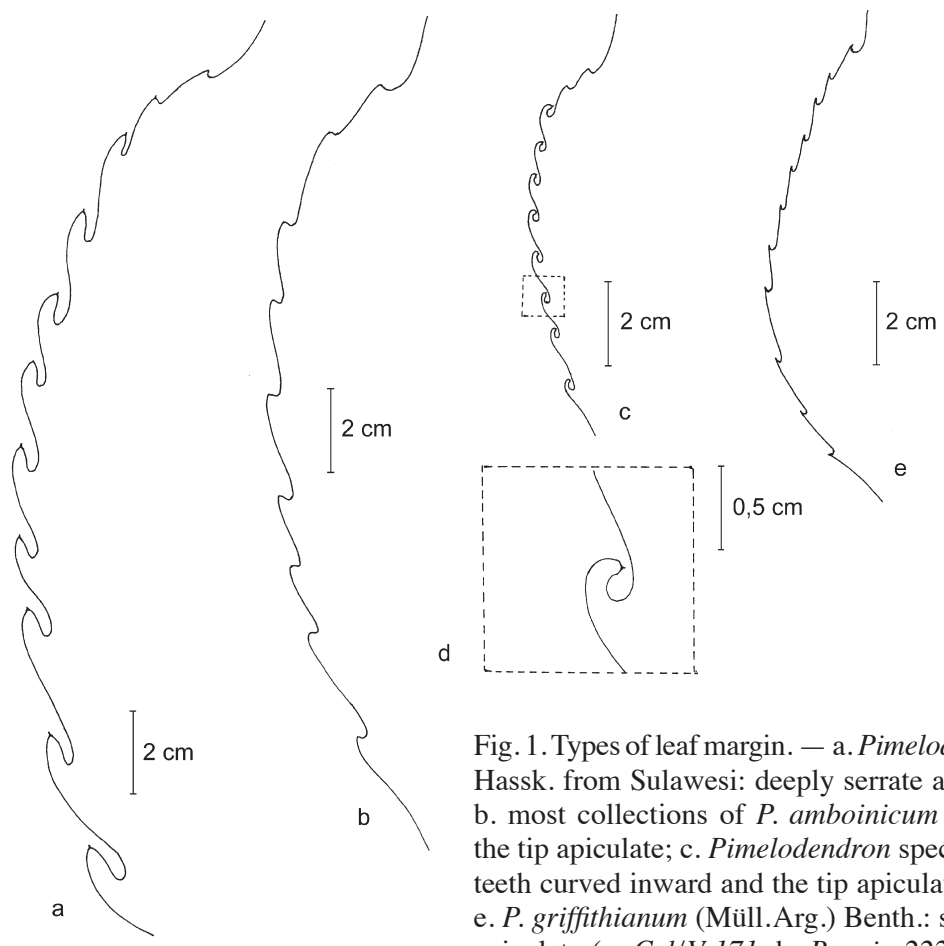

Fig. 1. Types of leaf margin. - a. Pimelodendron amboinicum Hassk. from Sulawesi: deeply serrate and the tip apiculate; b. most collections of P. amboinicum Hassk.: serrate and the tip apiculate; c. Pimelodendron spec. nov.?: serrate with teeth curved inward and the tip apiculate; d. detail of teeth; e. P. griffithianum (Müll.Arg.) Benth.: serrulate with the tip apiculate (a: Cel/V-171; b: Beguin 2227; c, d: Yates 1087; e: $S$ (Wright) 24717 ; all BO). 


\section{Inflorescences}

The staminate inflorescences are usually racemes (panicles in P. macrocarpum), which are subsessile or long peduncled, axillary and/or ramiflorous. The racemes are usually fascicles of more than one per axil, even up to 7 in $P$. zoanthogyne. The staminate inflorescences can be more than $10 \mathrm{~cm}$ long (P. macrocarpum), but are usually less than $7 \mathrm{~cm}$ long $(P$. amboinicum, $P$. griffithianum, $P$. zoanthogyne $)$. The pistillate inflorescences are racemes, up to $6 \mathrm{~cm}$ long in $P$. amboinicum, $P$. griffithianum, and $P$. zoanthogyne; and up to $10 \mathrm{~cm}$ long in P. macrocarpum.

\section{Bracts and bracteoles}

Bracts to the inflorescences are only found in staminate flowers of P. macrocarpum (one bract). The bracts of the staminate and pistillate flowers are normally triangular with an entire margin. The staminate flowers of $P$. amboinicum, $P$. griffithianum, and $P$. zoanthogyne have one bract, but $P$. macrocarpum has three bracts (a central large one and 2 smaller lateral called bracteoles). The tip of the bracts is entire, but serrate in P. amboinicum. The bracts sometimes possess two glands at the base, one on each side. The pistillate flowers of $P$. amboinicum have three bracts (a central large one and 2 smaller lateral bracteoles); those of $P$. griffithianum, $P$. macrocarpum, and P. zoanthogyne only have one bract.
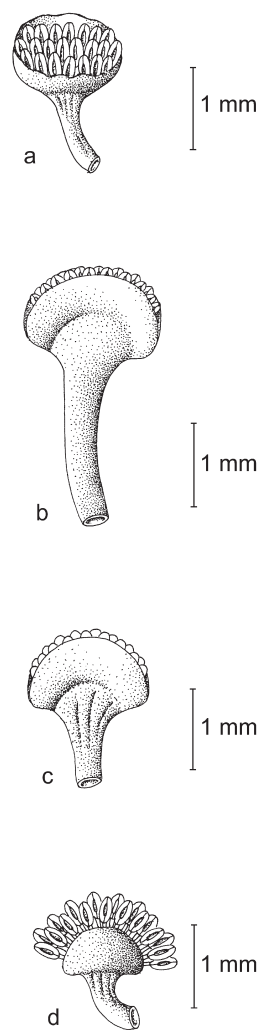
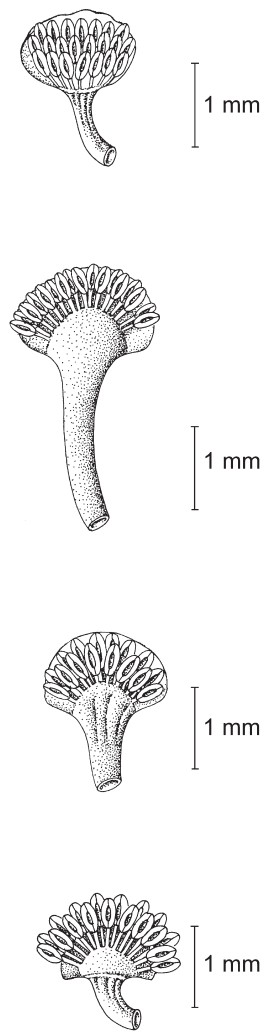

Fig. 2. Types of male flowers and stamens arrangement.Left: staminate flower with sepals; right: staminate flower with part of sepals removed showing the stamens arranged. - a. P. amboinicum Hassk.; b. P. griffithianum (Müll.Arg.) Benth.; c. P. macrocarpum J.J. Sm.; d. P. zoanthogyne J.J. Sm. (a: Bogor Botanical Garden IX.A.135a; b: Kostermans 8773, BO; c: Zwaan 32 T1.P36, BO; d: Bogor Botanical Garden XI.B.XII.126). 


\section{Flowers}

Staminate flowers - The pedicels of $P$. amboinicum and $P$. macrocarpum are up to $4 \mathrm{~mm}$ long; while those of $P$. griffithianum and $P$. zoanthogyne are up to $7.5 \mathrm{~mm}$ long. The calyx is cup-shaped with two lobes, the lobes are only basally fused, the tip is usually entire but serrate in P. amboinicum. Pimelodendron griffithianum (Fig. 2b right), $P$. macrocarpum (Fig. 2c right), and $P$. zoanthogyne (Fig. 2d right) have stamens in two rows; while $P$. amboinicum has three rows (Fig. 2a right). The number of stamens varies within species: P. amboinicum (7-29), P. griffithianum (6-19), P. macrocarpum (15-20), P. zoanthogyne (7-18). The stamens may remain enclosed in the calyx: P. amboinicum (Fig. 2a left), P. griffithianum (Fig. 2b left), P. macrocarpum (Fig. 2c left), or can protrude as in P. zoanthogyne (Fig. 2d left).

Pistillate flowers - The pedicel is usually up to $3 \mathrm{~mm}$ long in P. amboinicum and $P$. zoanthogyne, but longer in $P$. griffithianum and $P$. macrocarpum (up to $12 \mathrm{~mm}$ long). The calyx is cupuliform with two lobes with usually an entire tip, but serrate in P. zoanthogyne. Pimelodendron griffithianum has scattered glands at the union of the basal two lobes (Fig. 3d); P. amboinicum only has glands at the union of the basal two lobes (Fig. 3a). The ovary comprises a varying number of locules per species: $P$. amboinicum 3 or 4, P. griffithianum 4-10, P. macrocarpum 15-21, and P. zoantho-
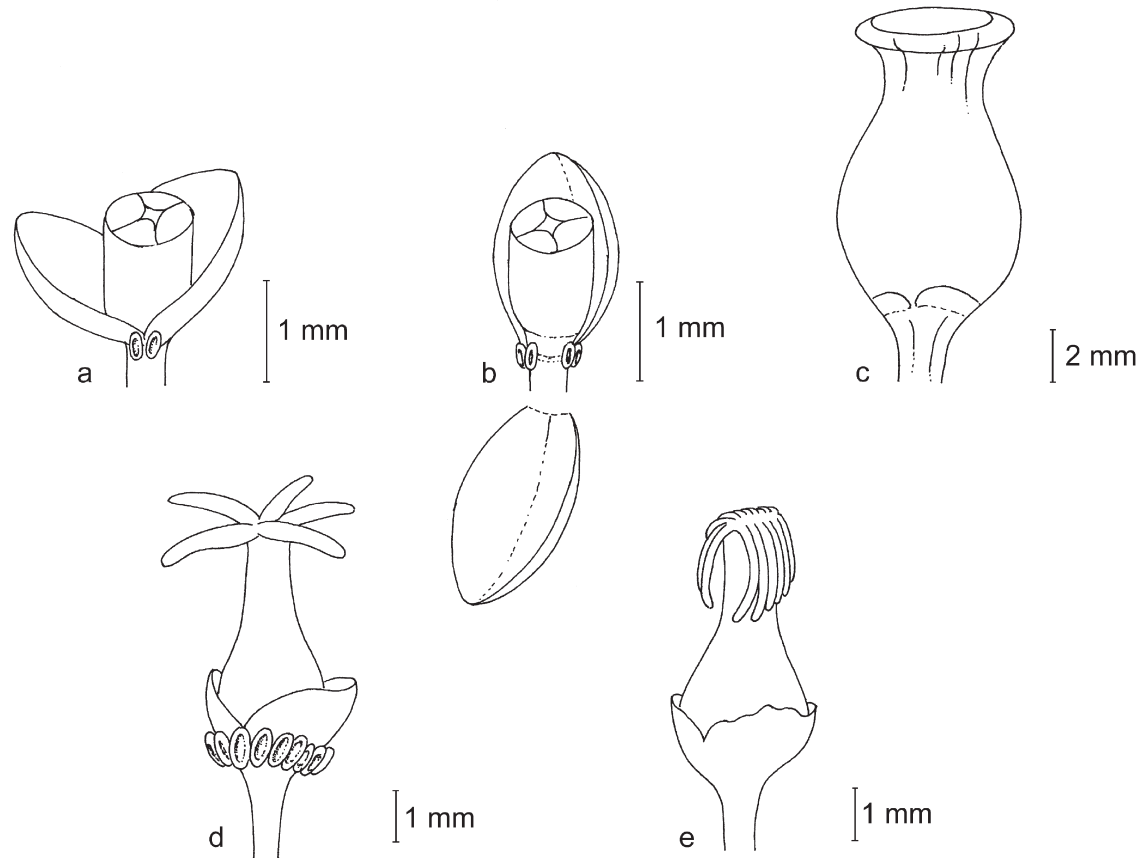

$1 \mathrm{~mm}$

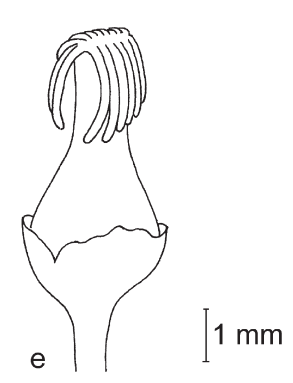

Fig. 3. Types of styles and stigmas. - a. Pimelodendron amboinicum Hassk.: lobes pulvinate and flat, with sepal showing glands at the union of the basal two lobes; b. P. amboinicum Hassk. with sepal opened showing glands; c. P. macrocarpum J.J. Sm.: lobes indistinct, flat; d. P. griffithianum (Müll.Arg.) Benth.: free and straight; e. P. zoanthogyne J.J. Sm.: connate and recurved (a, b: living collection Bogor Botanical Garden IX.C.68a, Bogor Botanical Garden; c: SAN (Wood) 16323, BO; d: Kostermans 10491, BO; e: Kostermans 11171, BO). 
gyne 10-15. Two species have sessile stigmas: the stigma lobes in P. amboinicum are pulvinate and flat (Fig. 3a, b), and in P. macrocarpum flat and somewhat indistinct (Fig. 3c). The short styles in P. griffithianum (Fig. 3d) are free and straight, whereas those in $P$. zoanthogyne (Fig. 3e) are connate and recurved.

\section{Fruits}

Pimelodendron griffithianum, P. macrocarpum, and P. zoanthogyne have orbicular drupes, they are pyriform in P. amboinicum, and conical in Pimelodendron spec. nov.? The diameter of the fruits is less than $3 \mathrm{~cm}$ in $P$. amboinicum, $P$. griffithianum, and Pimelodendron spec. nov.? and more than $5 \mathrm{~cm}$ in $P$. zoanthogyne and P. macrocarpum. The fruits are smooth, with the remnants of the stigmas still present (P. griffithianum, P. zoanthogyne, and Pimelodendron spec. nov.?) or absent (P. amboinicum and P. macrocarpum).

Seeds

Pimelodendron amboinicum has one seed per fruit. Pimelodendron griffithianum and P. zoanthogyne have 2-6 seeds per fruit, P. macrocarpum may have up to 11 seeds per fruit. The seed of Pimelodendron spec. nov.? is unknown. The shape of the seeds varies from globose (P. amboinicum) to reniform (P. griffithianum and P. macrocarpum) to ovate (P. zoanthogyne).

\section{TAXONOMY}

\section{PIMELODENDRON}

Pimelodendron Hassk. (1855) 140; Benth. \& Hook.f. (1880) 331; Hook.f. (1888) 468; Pax (1897) 96; Pax \& K. Hoffm. (1912) 54; J.J. Sm. (1924) 100; Ridl. (1924) 313; Whitmore (1972) 124; Airy Shaw (1980a) 196; (1980b) 666; (1981) 339; G.L. Webster (1994) 118; Radcl.-Sm. (2001) 350. - Carumbium Reinw. sect. Pimeleodendron Müll.Arg. (1866) 1143. - Type: Pimelodendron amboinicum Hassk.

Stomatocalyx Müll.Arg. (1866) 1142. - Type: Stomatocalyx griffithianus Müll.Arg. [= Pimelodendron griffithianum (Müll.Arg.) Benth.].

(Shrubs to) trees, dioecious. Bark always glabrous. Latex abundant, white. Indumentum consisting of simple hairs. Stipules absent. Leaves alternate, simple, in terminal groups due to sympodial growth; petiole terete, apically with transverse ridges adaxially when dry (absent in P. macrocarpum and Pimelodendron spec. nov.?), glabrous; blade elliptic to obovate, symmetrical, glabrous, smooth; base attenuate (except in $P$. macrocarpum), with two basal glands at lower surface; apex acute to cuspidate; margin serrulate, serrate to deeply serrate, without glands; venation penninerved, brochidodromous. Inflorescences racemes, in fascicles of more than 1 per axil, up to 7 in $P$. zoanthogyne (to panicles in staminate specimens of $P$. macrocarpum), axillary (to ramiflorous in staminate specimens); staminate inflorescences less than $7 \mathrm{~cm}$ long (except in P. macrocarpum); pistillate inflorescences less than $6.5 \mathrm{~cm}$ long (except in P. macrocarpum). Flowers single per node, in the axil of triangular pedicellate bracts, symmetric, apically acute; petals absent; disc absent. Without bracts to the staminate inflorescences (except in P. macrocarpum). The bracts of the staminate and pistillate flowers are normally triangular with an entire margin. Staminate flowers: bracts one (three bracts in P. macrocarpum: central one large and 2 smaller lateral bracteoles), 
tip entire, but serrate in $P$. amboinicum; calyx cup-shaped with two lobes, lobes only basally fused, tip usually entire but serrate in P. amboinicum; stamens 7-29, free, arranged in 2 rows ( 3 rows in $P$. amboinicum), enclosed in the calyx or protruding (in $P$. zoanthogyne); filaments very short or nearly as long as anthers; anthers dorsifixed; thecae opening latro-extrorsely with longitudinal slits; pistillode absent. Pistillate flowers: bracts one (three bracts in P. amboinicum: central one large and 2 smaller lateral bracteoles); calyx cupuliform with two lobes, the tip is usually entire but serrate in $P$. zoanthogyne; ovary cylindrical to oblong, number of locules 3-21, with 1 ovule per locule; stigma lobes simple, thin to thick, flat to recurved, free or connate. Fruit a pyriform, orbicular, or conical drupe, yellow/reddish when mature, glabrous, thickwalled, fleshy soft when fresh. Seeds globose, ovoid or reniform, half-enclosed by a broad, shallow multilobulate aril, 1-11 per fruit.

Distribution - An Australasian genus of five species distributed from the Malay Peninsula to New Guinea, Solomon Islands, and tropical NE Australia (Queensland).

\section{KEY TO THE MALESIAN SPECIES}

1a. Leaves shiny above when dry. Pistillate inflorescences 7-10 cm long; stigma with indistinct lobes (Fig. 3c). Staminate inflorescences panicles, up to $22 \mathrm{~cm}$ long. Fruits up to $13 \mathrm{~cm}$ diameter $\ldots \ldots \ldots \ldots \ldots \ldots \ldots \ldots$ 3.P. macrocarpum

b. Leaves dull above when dry. Pistillate inflorescences up to $6 \mathrm{~cm}$ long; stigma lobes distinct (Fig. 3a, 3b, 3d, 3e) (unknown for Pimelodendron spec. nov.?). Staminate inflorescences racemes, less than $7 \mathrm{~cm}$ long (unknown for Pimelodendron spec. nov.?). Fruits less than $7 \mathrm{~cm}$ diameter . . . . . . . . . . . . . . . 2

2a. Fruit conical, less than $3 \mathrm{~cm}$ diameter. Leaf margin serrate with the teeth curved inward (Fig. 1c, 1d), distance between teeth up to $1.5 \mathrm{~cm} \ldots \ldots \ldots \ldots \ldots$

5. Pimelodendron spec. nov.?

b. Fruit pyriform or orbicular, up to $6.6 \mathrm{~cm}$ diameter. Leaf margin serrulate, serrate, to deeply serrate, distance between teeth up to $3 \mathrm{~cm} \ldots \ldots \ldots \ldots \ldots$

3a. Fruit pyriform; remnants of stigma absent. Seeds globose, single per fruit. Stigma lobes pulvinate, flat (Fig. 3a, 3b). Stamens in 3 rows (Fig. 2a right). - Sulawesi, Moluccas, New Guinea . . . . . . . . . . . . . . 1. P. amboinicum

b. Fruit orbicular; remnants of stigma present. Seeds ovoid or reniform, 2-6 per fruit. Stigma lobes free and straight (Fig. 3d) or connate and recurved (Fig. 3e). Stamens

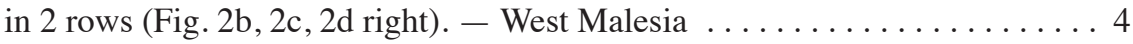

4a. Seeds reniform. Stigmas 4-10, free and straight (Fig. 3d). Pistillate sepals basally with scattered glands. Petiole $1-9.5 \mathrm{~cm}$ long; leaf margin serrulate $\ldots \ldots \ldots \ldots$

2.P. griffithianum

b. Seeds ovoid. Stigmas 10-15, connate and recurved (Fig. 3e). Pistillate sepals without basal glands. Petiole $3-12.5 \mathrm{~cm}$ long; leaf margin serrate . . . . . . . .

4. P. zoanthogyne

1. Pimelodendron amboinicum Hassk. - Fig. 1a, 1b, 2a, 3a, 3b; Map 1

Pimelodendron amboinicum Hassk. (1855) 140; Pax \& K. Hoffm. (1912) 54; J.J. Sm. (1924) 101; Whitmore (1966) 71; Airy Shaw (1976) 398; (1980a) 196; (1980b) 666; (1981) 339; (1982) 34 . Neotype: Beguin 2299 (holo BO; iso L, Manila), Moluccas, W Tobelo, Halmahera, see note 1. 
Pimelodendron papuanum Warb.(1894) 198; Pax \& K. Hoffm. (1912) 55. - Lectotype (selected here): Hellwig 464 (holo BO; iso B†), New Guinea, Kaiser Wilhelmsland, Finschhafen, bei Butaueng. Daphniphyllum conglutinosum Hemsl. (1895) 137. - Type: Comins 75 (holo K n.v.), Solomon Islands, San Cristoval.

Bennetia papuana Gilg (1919) 283. - Type: Ledermann 8945 (holo B†; iso L), Deutsch-New Guinea, Etappenberg.

?Pimelodendron naumannianum Pax \& K. Hoffm. (1924) 200. - Type: Naumann s.n. (holo B †), Indonesia, Lesser Sunda Islands, Timor, Nordseite der Kupang Bay; see note 2.

Tree 10-35 m tall, dbh 7-70 cm, bole 5-20 m high. Outer bark blackish brown to red-brown, smooth, not fissured, not peeling; inner bark yellow; sapwood and heartwood white. Leaves: petiole $1-10.5 \mathrm{~cm}$ long, apically with transverse ridges adaxially; blade elliptic (to obovate), $6.5-24.5$ by $3-12 \mathrm{~cm}$, length/width ratio $2-2.2$, coriaceous, base attenuate, usually with a pair of glands abaxially, apex acute to cuspidate, margin (rarely serrulate to) serrate (to deeply serrate, teeth 2-3 $\mathrm{mm}$ long, the tip apiculate, in some collections from several places of Sulawesi), distance between teeth in all other collections $1.4-3 \mathrm{~cm}(2-4 \mathrm{~cm}$ in some collections from several places of Sulawesi), upper surface dull when dry, veins prominent beneath, not prominent above, 5-11 pairs of lateral veins. Staminate inflorescences racemose, fascicles up to 6 per axil, $1-5.5 \mathrm{~cm}$ long, axillary and/or cauline; without bracts to the inflorescences; bracts to the flowers 3 , triangular, tip serrate, central one large, $1-1.5$ by $0.7-1.5 \mathrm{~mm}, 2$ smaller lateral bracteoles, c. 0.25 by $0.25 \mathrm{~mm}$. Staminate flowers $1-6.5$ by $2-4 \mathrm{~mm}$, yellow; pedicel $0.2-4$ by $0.2-1 \mathrm{~mm}$; calyx lobes $2-3.5$ by $1-2 \mathrm{~mm}$; tip serrate; margin serrate; stamens $7-29$, in 3 rows, filaments $0.25-1.5 \mathrm{~mm}$ long, anthers $0.25-1.25$ by 0.25-1 mm. Pistillate inflorescences solitary, 1-1.6 cm long; without bracts to the inflorescences; bracts to the flowers 3 , triangular, central one large, c. 1 by $1 \mathrm{~mm}, 2$ smaller lateral bracteoles, c. 0.5 by $0.5 \mathrm{~mm}$. Pistillate flower $3-3.5$ by c. $1 \mathrm{~mm}$; pedicel $1.5-2$ by c. $1 \mathrm{~mm}$; calyx lobes $1.5-2$ by $1-1.5 \mathrm{~mm}$, glands at the union of the basal two lobes; tip entire; margin entire; ovary $1.2-1.8$ by c. $1 \mathrm{~mm}$, locules 3 or 4 ; stigmas lobes pulvinate, flat. Fruits pyriform, $0.8-1.7 \mathrm{~cm}$ diam., young light green, mature reddish, glabrous; pedicel $0.6-2 \mathrm{~cm}$ long; remnants of stigmas absent. Seeds globose, one per fruit, $1-1.3$ by $0.7-1 \mathrm{~cm}$.

Distribution - Malesia: Sulawesi, Moluccas, Lesser Sunda Islands, New Guinea; Solomon Islands.

Habitat \& Ecology - Primary (mixed Dipterocarp) and secondary forest, rain forest pockets in coastal savannah, swamp forest, or edges of rivers; soil: sandy clay, volcanic, lime-stone. Altitude: sea level up to $1000 \mathrm{~m}$. Flowering and fruiting throughout the year.

Vernacular names - Sulawesi: Amead'a (Tabaur), gito (Tadjiosch), malala'a (Talaud, Salib), sinto (Moena), tambodja (Baree). Moluccas: Ai mulute, mamina (Maleisch, Amboisch), angalkenga, asare (Otimmer), dee, ereroe (Ambai), espahat (Boeroesch), gawi (Tobeloreesch), goro koeratji (Bacan), kaporaja (Ternate), lalagoe, lemtja, mamare, moi, moreala (Tobelasch), ngalim, o tigo-tigono, pake (Galelanesch), pekre (Kebar), pokopokor (Maleisch, Tobelo), posidi (Wajoli), roebi tima (Mangoli), sepahat (Boeroesch). New Guinea: komkwa (Manikiong), kimoko = mimika (Tarie), koro (Randawaja), koromi (Wandammen), bepie (Atam), marendom (Biak), diro (Sidei), joem (Mooi), sowgwa (Manikiong). Solomon Islands: Aisubu (Kwara'ae; Whitmore, 1966). 


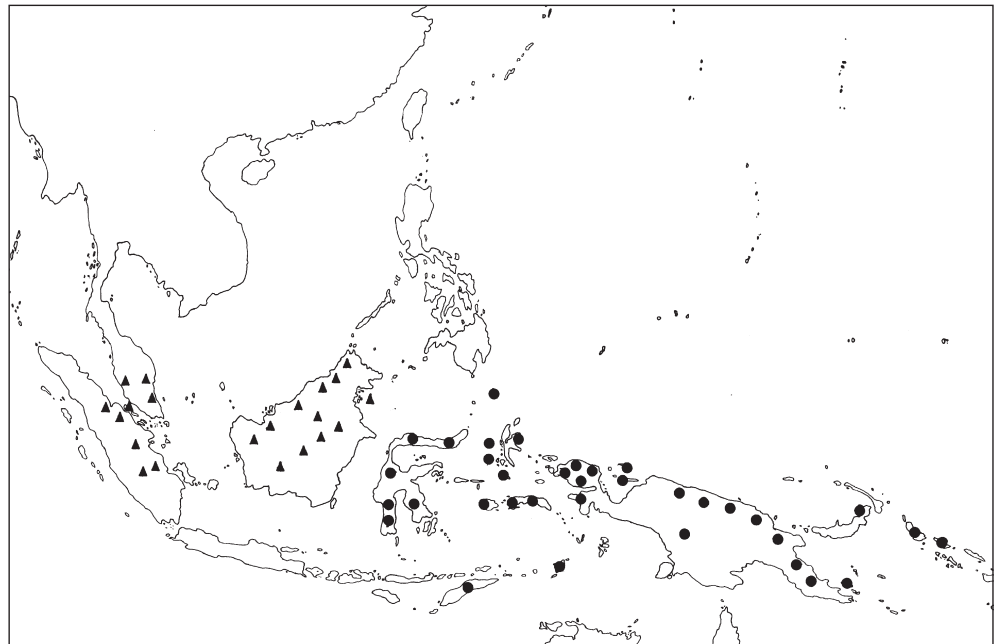

Map 1. Distribution of Pimelodendron amboinicum Hassk. (•) and P. griffithianum (Müll.Arg.) Benth. (山).

Notes -1 . The specimen described by Hasskarl was (probably) lost or he might have used living material to describe the plant and there is no herbarium material, so a neotype has been selected here.

2. The differentiating character for P. papuanum Warb. is the short pedicel of the staminate flower, less than $1 \mathrm{~mm}$ long (as opposed to $0.2-4 \mathrm{~mm}$ in typical P. amboinicum). Examination of several characters of many collections, e.g., staminate inflorescences, pedicel, staminate flower, calyx lobes, number of stamens, petiole length, length of leaf, leaf apex, margins, etc. all show a complete overlap between P. amboinicum and $P$. papuanum, leaving only the pedicel length as sole criterion to separate both species. This character is rather unreliable due to the variation of the pedicel length in the genus. Therefore, $P$. papuanum is here regarded as a synonym of $P$. amboinicum. Perhaps more pistillate material may reveal more differences.

3. Pimelodendron naumannianum (Timor), is only known from literature, the type is lost. Based on the description it is considered as a (new) synonym of P. amboinicum.

4. Several collections of $P$. amboinicum from Sulawesi in three different places: Malili-South Sulawesi (Cel/V-171, Cel/II-461), SE Sulawesi (Prawiroatmodjo \& Soewoko 2005), unknown places in Sulawesi (Elbert 3308, Kjellberg 1149) have leaves with deeply serrate margins (teeth $2-3 \mathrm{~mm}$ long and the tip apiculate), the distance between the teeth is $2-4 \mathrm{~cm}$, as opposed to $1.4-3 \mathrm{~cm}$ in all other collections. However, as this is the only difference, no taxonomic separation seems justified.

2. Pimelodendron griffithianum (Müll.Arg.) Benth. \& Hook.f. - Fig. 1e, 2b, 3d; Map 1

Pimelodendron griffithianum (Müll.Arg.) Benth. \& Hook.f. (1880) 331; Hook.f. (1888) 468; Pax \& K. Hoffm. (1912) 56; Ridl. (1924) 313; Whitmore (1972) 125; Airy Shaw (1975) 186; (1977) 80. - Stomatocalyx griffithianus Müll.Arg. (1866) 1142. - Lectotype (proposed here because of the epithet): Griffith s.n. (holo K n.v.), Malacca. 
Pimelodendron borneense Warb. (1894) 199; Pax \& K. Hoffm. (1912) 56. - Type: Beccari PB 293 (holo B $\uparrow$; iso BO), Borneo, Sarawak.

Pimelodendron acuminatum Merr. (1916) 74. - Type: Hose 240 (holo A photo; iso L), Sarawak, Baram District, Baram.

Pimelodendron papaveroides J.J. Sm. (1924) 104. - Type: Grashoff 755 (holo BO), Sumatra, Palembang, Banjoeasin- en Koeboestreken.

Tree 6-25 m tall, dbh10-91 cm, bole 8-12 m high. Outer bark light brown to reddish brown, smooth to rugose, thin, soft; inner bark light brown with pale yellow sap, c. 2 $\mathrm{mm}$ thick, with slight fruit smell; sapwood pale yellow, soft. Leaves: petiole 1-9.5 cm long, apically with transverse ridges adaxially; blade elliptic (to obovate), 6.5-18 by $2.5-9 \mathrm{~cm}$, length/width ratio $2-2.6$, thinly coriaceous, base attenuate, usually with a pair of basal glands abaxially, apex acuminate to cuspidate, margin serrulate with the tip apiculate, distance between teeth 1-2.1 cm, upper surface dull when dry, veins prominent beneath, not prominent above, 6-8 pairs of lateral veins. Flowers yellowish green, calyx greenish brown. Staminate inflorescences racemose, fascicles up to 4 per axil, 1-6 cm long; without bracts to the inflorescences; bracts to the flowers 3 , triangular (P. acuminatum has bracts with glands), tip entire, central one large, c. 1 by $1 \mathrm{~mm}, 2$ smaller lateral bracteoles, c. 0.25 by $0.25 \mathrm{~mm}$. Staminate flowers $3.8-8.5$ by 3-5.8 mm; pedicel 1.5-6 by 1-1.5 mm (some collections from Borneo: Endert 4913, KEP FRI 41342, Kostermans 21385, Van Niel 4051; and from Sumatra: Hotta \& Okada 1608 , have pedicels of 5.5-7.5 mm long); calyx lobes $2-5.5$ by $1.5-3 \mathrm{~mm}$, margin entire; stamens $6-19$, in 2 rows, filaments $0.25-1 \mathrm{~mm}$ long, anthers $0.1-1$ by $0.25-1$ $\mathrm{mm}$. Pistillate inflorescences fascicles up to 2 per axil, 2-6 $\mathrm{cm}$ long; without bracts to the inflorescences; bracts to the flowers 1 , triangular, c. 1 by $1 \mathrm{~mm}$, tip entire. Pistillate flowers $7.5-12$ by $3.8-6 \mathrm{~mm}$; pedicel $3.2-6$ by $1-1.5 \mathrm{~mm}$; calyx lobes $2-4$ by $1.5-3$ $\mathrm{mm}$, with scattered glands at the union of the basal two lobes; tip entire; margin entire; ovary c. 3 by $2 \mathrm{~mm}$, locules $4-10$, stigmas free and straight. Fruits orbicular, $1.2-3 \mathrm{~cm}$ diam., glabrous, pale green (immature); pedicel $0.5-3.5 \mathrm{~cm}$ long; remnants of stigmas present. Seeds reniform, 3 per fruit, $0.8-1.9$ by $0.6-1.2 \mathrm{~cm}$.

Distribution - Peninsular Thailand (Airy Shaw, 1977), Malay Peninsula, Sumatra, Borneo.

Habitat \& Ecology - Wet forest, secondary forest, pole forest, semi-swamps, along logging roads or on hill slopes; soil dry to wet, sand or clay. Altitude: sea level to $900 \mathrm{~m}$. Flowering: January to April, July to December; fruiting: April to October, December.

Vernacular names - Sumatra: djeloetoeng pipih, lantjat imbo (Batak, Dairi), lempanai (Palembang), majang ukit (Batak, Toba), njatoh (Maleisch), panai-panai (Maleisch), paoeh hoetan (Maleisch). Borneo: bua mambur, mampoeloet (Dajaksch), njulir, pulai, tampang (Bekoempai, Sijang), perah ikan (Malay), kelampai sitak (Iban).

Notes -1 . There is a complete overlap in measurements between $P$. borneense and $P$. griffithianum. However, this is mainly based on staminate specimens, more pistillate specimens are required for a well founded opinion about the synonymy of $P$. borneense. For the time being I agree with Airy Shaw (1975) that $P$. borneense is a synonym of P. griffithianum.

2. There are no real differences between P. acuminatum and P. griffithianum. Sometimes $P$. acuminatum has staminate bracts with glands, but this difference does not merit a special taxonomic status. 
3. Based on different measurements of staminate and pistillate specimens, and the presence of basal glands on the persistent sepals of the fruits no difference between $P$. papaveroides and $P$. griffithianum could be found.

4. Some collections from Borneo (Endert 4913, KEP FRI 41342, Kostermans 21385, Van Niel 4051) and from Sumatra (Hotta \& Okada 1608) have 7-9.5 mm long staminate flowers and pedicels of 5.5-7.5 mm long. These characters are very different from all other specimens, but there is still an overlap. Therefore, these specimens are not given a new status.

\section{Pimelodendron macrocarpum J.J. Sm. - Fig. 2c, 3c; Map 2}

Pimelodendron macrocarpum J.J. Sm. (1924) 103; Airy Shaw (1971) 551; Whitmore (1972) 126; Airy Shaw (1975) 187; (1981) 339. - Lectotype (selected here): Dumas 1509 (holo BO; iso L), Sumatra, Palembang, Rawas.

Tree up to $30 \mathrm{~m}$ tall, dbh $20-40 \mathrm{~cm}$. Bark brown, fissured, glabrous. Leaves: petiole 1-8 cm long, apically without transverse ridges adaxially; blade elliptic to obovate, $5.5-20$ by $2-7.5 \mathrm{~cm}$, length/width ratio $2.1-2.8$, thinly coriaceous, base attenuate, usually without a pair of basal glands abaxially, apex cuspidate, margin mostly serrulate (or serrate) with the tip apiculate, distance between teeth 1-2.5 cm; upper surface shiny when dry; venation raised on lower surface, not raised above, 6-9 pairs of lateral veins. Staminate inflorescences panicles, $14-22 \mathrm{~cm}$ long; bracts to the inflorescences 1 , triangular, c. 1 by $1 \mathrm{~mm}$; bracts to the flowers 3 , triangular, tip entire, central one large, c. 1 by $1 \mathrm{~mm}, 2$ smaller lateral bracteoles, c. 0.25 by $0.25 \mathrm{~mm}$. Staminate flowers $3-4$ by $2.5-4 \mathrm{~mm}$; pedicel $1-3$ by c. $0.5 \mathrm{~mm}$; calyx lobes $3-4$ by $2-2.5 \mathrm{~mm}$; tip entire; margin entire; stamens 15-20, in 2 rows, filaments c. 2 mm long, anthers $1-2$ by c. $0.75 \mathrm{~mm}$. Pistillate inflorescences $7-10 \mathrm{~cm}$ long; without bracts to the inflorescences; bracts to the flowers 1 , cup-shaped c. 3.5 by c. $1.5 \mathrm{~mm}$. Pistillate flowers $17-22$ by 6-10 mm; pedicel $6-12$ by $3-4 \mathrm{~mm}$; calyx lobes c. 5 by $3 \mathrm{~mm}$, without basal glands;

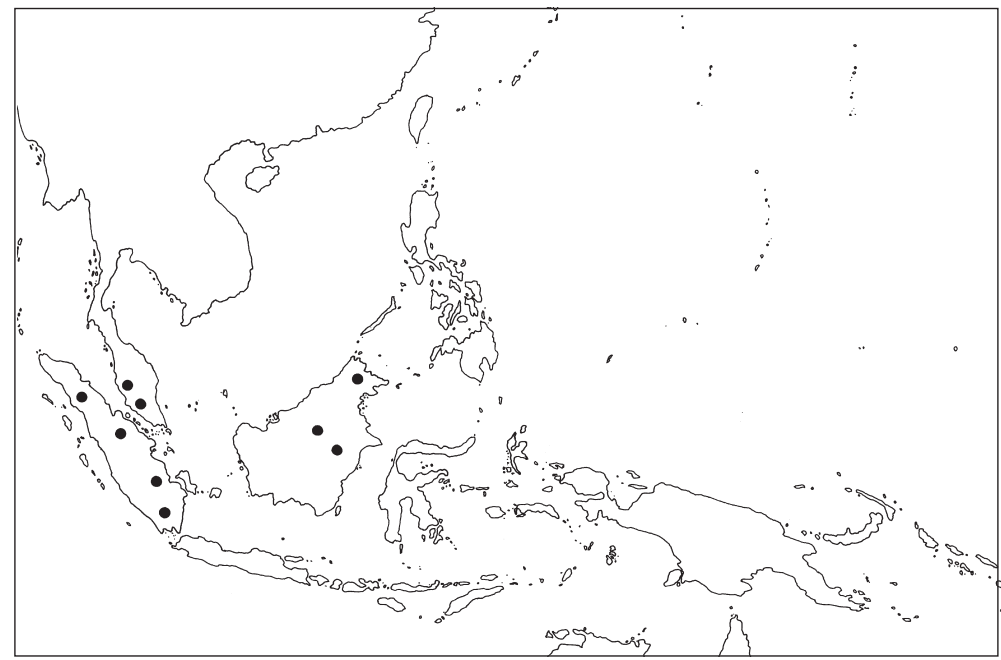

Map 2. Distribution of Pimelodendron macrocarpum J.J. Sm. 
tip entire; margin entire; ovary c. 9 by $6-9 \mathrm{~mm}$, locules $15-21$; stigma lobes indistinct, flat. Fruits orbicular, 5-13 cm diam., yellow, with white latex, fragrant; pericarp c. 2 $\mathrm{mm}$ thick; pedicel not seen; remnants of stigmas absent. Seeds reniform, c.11 per fruit, $2-3$ by $1.7-3.4 \mathrm{~cm}$.

Distribution - Malay Peninsula, Sumatra, Borneo.

Habitat \& Ecology - Forest on low undulating country. Altitude: 5-550 m. Flowering: April, August, September; fruiting: February, July, September.

Vernacular names - Malay Peninsula: tuba ikan (Malay). Sumatra: balam riedam (Palembang), balam terong (Palembang), dangkoe (Riau, Palembang), gango (Rawas). Borneo: ketong murung (Malay, Dajak).

Note - Typical for this species are the large fruits with many locules.

\section{Pimelodendron zoanthogyne J.J. Sm. - Fig. 2d, 3e; Map 3}

Pimelodendron zoanthogyne J.J. Sm. (1924) 106; Airy Shaw (1975) 187. - Lectotype (selected here): Hallier 866 (holo BO; iso L), Borneo.

Tree 10-24 m tall, dbh 5-45 cm, bole c. $12 \mathrm{~m}$ high. Outer bark pale brownish, smooth, not fissured, not peeling, c. $5 \mathrm{~mm}$ thick; inner bark c. $3 \mathrm{~mm}$ thick, with much pale yellow latex; sapwood pale yellowish; wood very hard. Leaves: petiole 3-12.5 $\mathrm{cm}$ long, apically with transverse ridges adaxially; blade elliptic, $4-20.5$ by $2-10 \mathrm{~cm}$, length/width ratio $2-2.1$, thinly coriaceous, base attenuate, usually with a pair of glands abaxially, apex cuspidate (to rarely acuminate), margin serrate or rarely serrulate with the tip apiculate, distance between teeth 1-3 cm; upper surface dull when dry; venation raised on lower surface, not raised above, 7-12 pairs of lateral veins. Staminate inflorescences racemose, green when young, fascicles up to 4 per axil, 2-4.5 cm long; without bracts to the inflorescences; bracts to the flowers 3 , triangular, tip entire, central one large, c. 1 by $1 \mathrm{~mm}$, rarely with a gland at the base, 2 smaller lateral bracteoles,

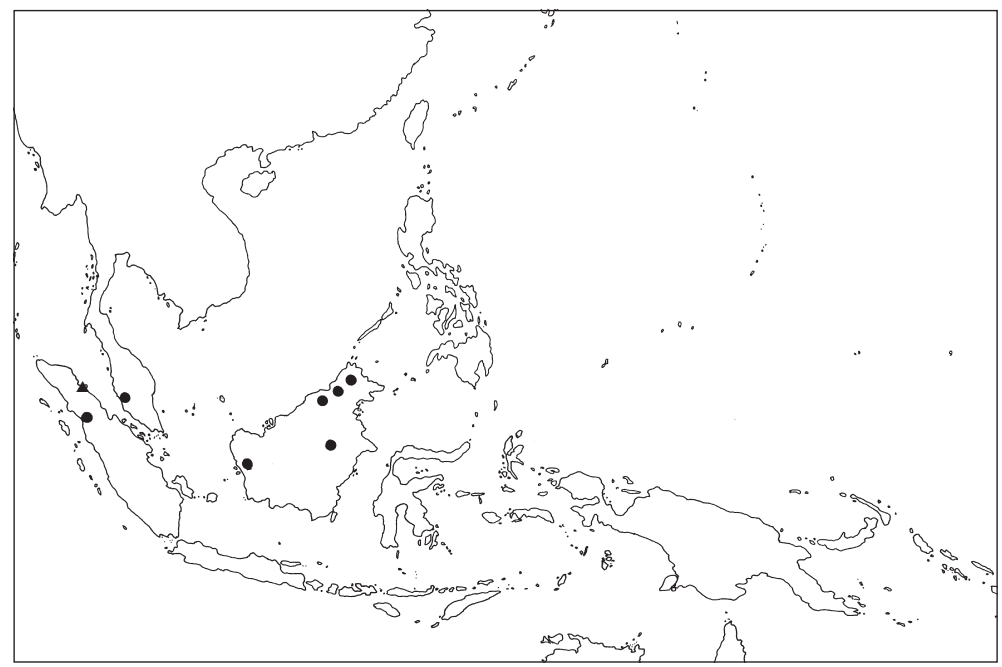

Map 3. Distribution of Pimelodendron zoanthogyne J.J. Sm. (•) and Pimelodendron spec. nov.? 
c. 0.25 by $0.25 \mathrm{~mm}$. Staminate flowers $4-9.5$ by $2-5 \mathrm{~mm}$, yellow; pedicel $2-5$ by c. 1 $\mathrm{mm}$; calyx lobes $2-5$ by $1.2-3 \mathrm{~mm}$; tip entire; margin entire; stamens $7-18$, in 2 rows, filaments $0.25-1.5 \mathrm{~mm}$ long, anthers $0.5-1$ by $0.2-0.5 \mathrm{~mm}$. Pistillate inflorescences solitary, 2.5-3 cm long; without bracts to the inflorescences; bracts to the flowers 1 , triangular, c. 1 by $1 \mathrm{~mm}$. Pistillate flowers c. 6 by $5 \mathrm{~mm}$, yellow; pedicel c. 1.5 by c. 1 $\mathrm{mm}$; calyx lobes c. 5 by $3 \mathrm{~mm}$, without basal glands, tip serrate, margin serrate; ovary c. 3 by $1 \mathrm{~mm}$, locules 10-15, stigmas connate and recurved. Fruits orbicular, 1.4-6.6 $\mathrm{cm}$ diam., yellowish, glabrous, wall soft, thin, flesh pale yellow, with abundant milky latex; pedicel $2.5-4.5 \mathrm{~cm}$ long; remnants of stigmas present. Seeds ovoid, 2-6 per fruit, $2-2.5$ by $1-1.4 \mathrm{~cm}$.

Distribution - Peninsular Malaysia (Perak), Sumatra (Aceh), Borneo.

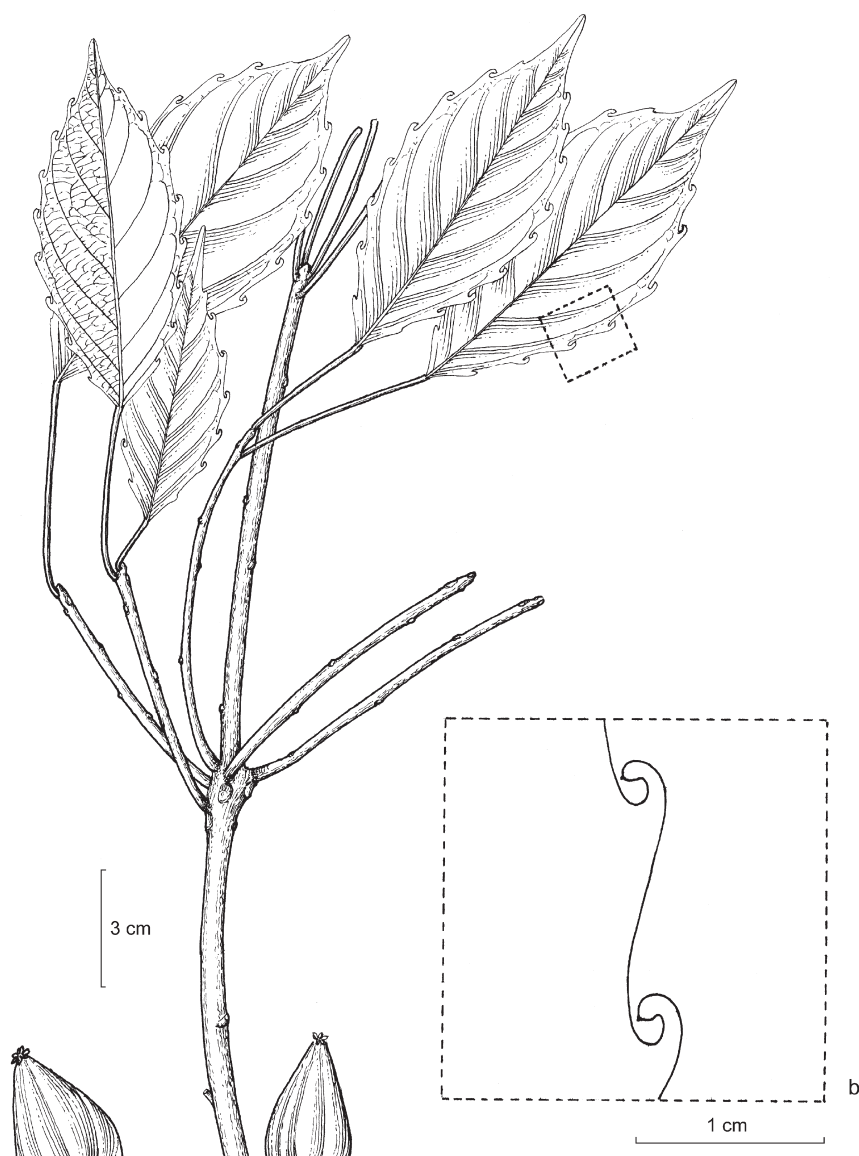

Fig. 4. Pimelodendron spec. nov.? a. Habit of fruiting plant; b. detail of leaf margin (Yates 1087, BO). 
Habitat \& Ecology - Primary lowland dipterocarp forest, depleted primary forest, disturbed peat swamp forest, on level alluvial flats to small ridges; soil: clay loam soil, deep sandy clay with stones. Altitude: 30-200 m. Flowering: April to June, August to October; fruiting: July, December.

Vernacular names - Borneo: kelampai sitak (Iban).

Uses - Fruit edible, flesh with sourish odour and with an insipid or sweetish taste.

Note - This species closely resembles $P$. griffithianum especially in the staminate flowers. Typical are the pistillate flowers with 10-15 connate and recurved stigmas and the ovoid seeds. Also typical are the long petioles, but here there is overlap with other species.

\section{Pimelodendron spec. nov.? - Fig. 1c, 1d, 4; Map 3}

Habit unknown. Bark pale brownish; branchlets and twigs terete, pale brownish, smooth, not fissured. Leaves: petiole 4.5-6 cm long, apically without transverse ridges at the adaxial side, pale brownish; blade elliptic, $9.5-12$ by $3.5-5 \mathrm{~cm}$, length/width ratio 2.4-2.7, coriaceous; base attenuate, with a pair of glands abaxially; the leaf apex cuspidate; margin serrate, the teeth $0.5-1 \mathrm{~mm}$ long, curved inward and the tip apiculate, distance between teeth $0.7-1.5 \mathrm{~cm}$; upper surface dull when dry; venation raised on lower surface, not raised above. Inflorescences and flowers unknown. Infructescences racemose, 3-4 cm long. Bracts and bracteoles not seen. Fruits conical, c. 3 by 2.1-2.5 $\mathrm{cm}$ diam., 4-locular, glabrous; pedicel 1-1.2 cm long, glabrous; remnants of stigmas present. Seeds not seen.

Distribution - East coast of Sumatra.

Notes -1 . The cited collection consists only of leaf and infructescences in one collection. This material resembles $P$. griffithianum (4-10 locules) very closely, but it is different in its conical fruits and serrate leaf margins. No information is given about the plant or about particular ecological circumstances. The inadequate material and the complete absence of additional information make it impossible to say whether the collection belongs to $P$. griffithianum or represent a new taxon. Therefore it seems wise to separate it from the rest of Pimelodendron without naming it, until more material becomes available.

2. Based on Yates 1087 (BO), east coast of Sumatra.

\section{EXCLUDED SPECIES}

Pimelodendron dispersum Elmer (1908) 308. - Type: Elmer 7245 (holo PNH n.v.; iso L!), Philippines, Leyte, Province of Leyte, Palo = Actephila excelsa (Dalzell) Müll.Arg. var. javanica (Miq.) Pax \& K. Hoffm. (see Airy Shaw, 1975).

\section{ACKNOWLEDGEMENTS}

The directors of BO, CANB, L, SAR and the botanical garden, Kebun Raya, in Bogor are thanked for use of their material. Very special thanks are due to Peter van Welzen for reviewing the manuscript, critical comments, and support. I would like to thank the Bureau of Leiden University and the GEF Project-BCP for their grant with which I could visit the Nationaal Herbarium Nederland in Leiden and I am grateful to Prof. Dr. P. Baas, the Director of the Nationaal Herbarium Nederland, for his hospitality. Thanks are due to Sobari who prepared the illustrations. 


\section{REFERENCES}

Airy Shaw, H.K. 1971. Notes on Malesian and other Asiatic Euphorbiaceae. CXLVII. Pimelodendron macrocarpum in Malaya and Borneo. Kew Bull. 25: 551, 552.

Airy Shaw, H.K. 1975. The Euphorbiaceae of Borneo. Kew Bull. Add. Ser. 4: 25, 186, 187.

Airy Shaw, H.K. 1976. New or noteworthy Australian Euphorbiaceae. Kew Bull. 31: 398.

Airy Shaw, H.K. 1977. Additions and corrections to Euphorbiaceae of Siam. Kew Bull. 32: 80, 81.

Airy Shaw, H.K. 1980a. The Euphorbiaceae of New Guinea. Kew Bull. Add. Ser. 8: 196, 197.

Airy Shaw, H.K. 1980b. A partial synopsis of the Euphorbiaceae-Platylobeae of Australia (excluding Phyllanthus, Euphorbia and Calycopeplus). Kew Bull. 35: 666, 667.

Airy Shaw, H.K. 1981. The Euphorbiaceae of Sumatra. Kew Bull. 36: 339.

Airy Shaw, H.K. 1982. The Euphorbiaceae of Central Malesia (Celebes, Moluccas, Lesser Sunda Is.). Kew Bull. 37: 34.

Bentham, G. \& J.D. Hooker. 1880. Genera Plantarum 3: 331, 332. Reeve \& Co., Londini.

Burkill, I.H. 1935. A dictionary of the economic products of the Malay Peninsula 2: 1727. Crown Agents for the Colonies, London.

Elmer, A.D.E. 1908. A century of new plants. Leafl. Philipp. Bot. 1: 308.

Esser, H.-J., P.C. van Welzen \& T. Djarwaningsih. 1997. A phylogenetic classification of the Malesian Hippomaneae (Euphorbiaceae). Syst. Bot. 22: 617-628.

Gilg, E.F. 1919. Die bis jetzt aus Neu-Guinea bekannt gewordenen Flacourtiaceen. Bot. Jahrb. Syst. 55: 283 , f. 6.

Greuter, W., J. MacNeill, F.R. Barnie, H.M. Burdet, V. Demoulin, T.S. Filgueiras, D.H. Nicolson, P.C. Silva, J.E. Skog, P. Trehane, N.J. Turland \& D.C. Hawksworth. 2000. International Code of Botanical Nomenclature (Saint Louis Code). Koeltz Scientific Books, Königstein.

Hasskarl, J.K. 1855. Brief van den Heer Hasskarl aan den Secretaris der Natuurkundige Afdeeling van de Koninklijke Akademie van Wetenschappen te Amsterdam. Verslagen Meded. Afd. Natuurk. Kon. Akad. Wetensch. 4: 140.

Hasskarl, J.K. 1857. Genera aliquot nova horti botanici Bogoriensis. Flora 40: 534, 535.

Hasskarl, J.K. 1858. Hortus Bogoriensis Descriptus sive Retziae editio nova valde aucta et emendata: 68. Günst, Bonnae.

Hemsley, W.B. 1895. Flora of the Solomon Islands. Bull. Miscell. Inform.: 137.

Heyne, K. 1927. De Nuttige Planten van Indonesie 1: 960. Van Hoeve, 's-Gravenhage/Bandung.

Hooker, J.D. 1888. Flora of British India V: 468. Reeve \& Co., London.

Merrill, E.D. 1916. Notes on the Flora of Borneo. In: A.J. Cox \& E.D. Merrill (eds), Philipp. J. Sci., Bot. 11: 74, 75 .

Müller Argoviensis, J. 1866. Euphorbiaceae-Hippomaneae. In: A. de Candolle (ed.), Prodromus Systematis Naturalis Regni Vegetabilis 15, 2: 1142, 1143. Parisiis, Victoris Masson et Filii.

Pax, F. 1897. Euphorbiaceae. In: A. Engler \& K. Prantl (eds), Die natürlichen Pflanzenfamilien 3, 5: 96. Engelmann, Leipzig.

Pax, F. \& K. Hoffmann. 1912. Euphorbiaceae-Hippomaneae. In: A. Engler (ed.), Das Pflanzenreich IV.147.v.: 54-56. Engelmann, Leipzig.

Pax, F. \& K. Hoffmann. 1924. Euphorbiaceae-Additamentum VII. In: A. Engler (ed.), Das Pflanzenreich IV.147.xvii: 200. Engelmann, Leipzig.

Perry, L.M. \& M. Judith. 1980. Medicinal plant of East and Southeast Asia. Attributed properties and uses: 151. MIT Press, London.

Radcliffe-Smith, A. 2001. Genera Euphorbiacearum: 350, 351. Royal Botanic Gardens, Kew.

Ridley, H.N. 1924. The Flora of the Malay Peninsula. 3: 313. Reeve \& Co., London.

Smith, J.J. 1924. Plantae novae vel criticae ex Herbario et Horto Bogoriensi. III. Bull. Jard. Bot. Buitenzorg III, 6: 100-107.

Warburg, O. 1894. Plantae Hellwigianae. Bot. Jahrb. Syst. 18: 198, 199.

Webster, G.L. 1994. Synopsis of the genera and suprageneric taxa of Euphorbiaceae. Ann. Missouri Bot. Gard. 81: 33-144.

Whitmore, T.C. 1966. Guide to the forests of the British Solomon Islands: 71. Oxford University Press, Oxford.

Whitmore, T.C. 1972. Tree Flora of Malaya 2: 124-126. Longman, London. 


\section{IDENTIFICATION LIST}

The numbers after the collecting numbers refer to:

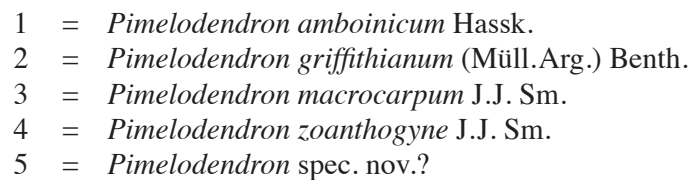

Aet 518: 1 - Aet \& Idjan 661: 1; 747: 1; 748: 1 - Ahmad 94499: 3 - Arbain DA 718: 2 - Arifin 9: 2 - Ashton 5947: 2.

bb series 6730: 2; 9270: 2; 10824: 3; 10952: 2; 11021: 2; 17817: 2; 21102: 1; 21908: 1; 23776: 1; 23858: $2 ; 24352$ : $1 ; 24429: 1 ; 24873: 1 ; 27431: 2 ; 27458: 2 ; 27466: 2 ; 27555: 2 ; 27629: 2 ; 28427$ :

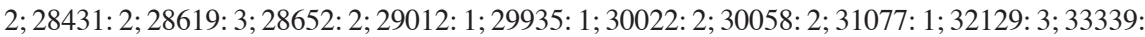
1;33367: $1 ; 33385: 1 ; 33411: 1 ; 33447: 1 ; 33594: 1 ; 33611: 1 ; 33639: 1 ; 34764: 3$ - Beccari PB 293: 2 - Beguin 555: 2; 1898: 1; 2227: 1; 2299: 1 - Bloembergen 475: 1 - Boerlage 702: 1 - Bogor Botanical Garden IX.A.82: 1; IX.A.128 a: 1; IX.A.133: 1; IX.A.133a: 1; IX.A.135: 1; IX.A.135a: 1; IX.A.145: 1; IX.A.145a: 1; IX.C.68a: 1; XI.B.XII.126: 4; XI.B.XVII.201: 4; XII.B.IX.3: 1 - Brass 13571: 1 - Brass \& Versteegh 13190: 1 - BRUN series 667: 2; 734: 2; 846: 2; 5947: 2; 10536: 2 - Brunig 1036: 2 - Burley, Tukirin \& Ismail 4399: 1 - Burley, Tukirin et al. 1591: 2 - Buwalda 460: 1; 4797: 1; 6377: 2; 6730:2 - BW series 1105: 1; 1133: 1; 1136: 1;

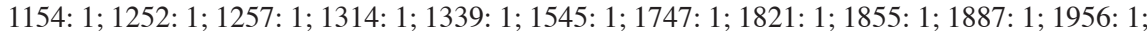
1994: 1 ; 2090: 1 ; 2132: 1 ; 2136: 1 ; 2671: 1 ; 2762: 1 ; 4644: 1 ; 6671: 1 ; 6834: 1 ; 7065: 1; 7066: 1 ; 7076: 1 ; 7627: 1 ; 7665: 1 ; 7824: 1; 8155: 1; 9090: 1; 9104: 1; 9570: 1 ; 9829: 1; 9836: 1; 9907: 1 ; 10091: 1 ; 10099: 1 ; 10684: 1 ; 11724: 1 ; 12121: 1 ; 12275: 1 ; 12316: 1; 12904: 1 ; 13015: 1.

Cel series Cel/II-461: 1; Cel/V-171: 1 - Church \& Mahyar 5335: 2; 5336: 2; 5337: 4 - Craven \& Schodde 701: 1.

Darbyshire 901: 1 - De Bell 16: 1 - De Haan 44: 1; 49: 1; 415: 1 - De Jong 677: 2 - De Vogel 1421: 4; 3479: 1; 3758: 1 - De Wilde \& De Wilde-Duyfjes 13582: 3; 13900: 3 - Dorst \& Thorenaar 32T1P90: 3 - Dumas 1509: 3.

Elbert 3308: 1 - Endert 3483: 2; 4913: 2.

Grashoff 304: 3; 755: 2 - Gray 5215: 1 .

Hallier 866: 4 - Haviland 3117: 2 - Hellwig 464: 1 - Hemitmuch 37194: 2 - Hoogland \& Craven 10307: 1 - Hose 240: 2; 295: 2; 304: 2 - Hotta \& Okada 1608: 2.

Idjan \& Muchtar 271: 1 .

Jacobs 5189: 2; 9529: 1 - JPM \& Ismail 5121: 1.

Kairo 186: 1 - Kajewski 2464: 1; 2694: 1 - KEP series 80845: 3 - KEP FRI series 6030: 4; 8598: 2; 41285: 2; 41342: 2 - Kiah 18187: 3 - Kjellberg 1149: 1 - Kornassi 960: 1 - Kostermans 12: $1 ; 72: 1 ; 107: 1 ; 144: 1 ; 163: 1 ; 198: 1 ; 243: 1 ; 433: 1 ; 457: 1 ; 490: 1 ; 6443: 2 ; 6676: 2 ; 6733$ : 2; 8770: $2 ; 8773: 2 ; 10491: 2 ; 11171: 4 ; 12540 B: 2 ; 21385: 2 ; 29012: 1$ - Kostermans \& Soegeng 197: 1 ; 486: 1 ; 545: 1 - Kostermans \& Tangkilisan 59: 1 .

LAE series 52113: 1; 52777: 1; 56275: 1; 61206: 1; 68757: 1; 68845: 1 - Lam 3043: 1; 3335: 1 — Laumonier TFB 3755: 1 - Lundquist 19: 1; 83: 1; 102: 1; 128: 1.

Malessy 2: 1 - Matatula 10: 1 - McDonald \& Ismail 3717: 1 - Meijer 10735: 1 - Muchtar 49A: 3.

NGF series 1206: 1; 1401: $1 ; 3918: 1 ; 4709: 1 ; 5439: 1 ; 6642: 1 ; 7370: 1 ; 8845: 1 ; 8992: 1 ; 10032: 1$; 10315: $1 ; 10549$ : 1 ; 11582: 1 ; $11925: 1 ; 12954: 1 ; 13044: 1 ; 15577: 1 ; 18963$ : 1 ; 22266: 1 ; 22306: 1; 23947: 1; 25304: 1; 25384: 1; 26936: 1; 33420: 1; 34305: 1; 43838: 1; 48002: 1; 48344: 1 .

Oersipuny 244: 1 .

Pickles 3442: 4 - Pleyte 210: 1; 1045: 1 - Prawiroatmodjo \& Soewoko 2005: 1 - Pulle 14: 1; 22: 1

Ramlanto 920: 1 - Reksodihardjo 421: 1 - Richards 2251: 2; 2364: 2 - Robinson 174: 1 - Rutten 1705: 1 . 
S series 22160: 2; 22614: $2 ; 24615: 4 ; 24717: 2 ; 25975: 2 ; 26135: 4 ; 27638: 2 ; 29057: 4 ; 32214$ : $2 ; 32512: 2 ; 36642: 2 ; 37959: 2 ; 38064: 2 ; 41204: 2 ; 41245: 2 ; 43048: 2 ; 43710: 2 ; 44079: 2$; 60132: 2; 61703: 2; 62144: 2 - Saanan 54: 1 - SAN series 15136: 2; 16323: 3; 16945: 4; 63197: 2; 72181: 2; 76101: 2; 80573: 2 - Sayers 24136: 1 - SF series 34533: 2; 37717: 2; 38929: 2 - Sidiyasa PBU 693: 2 - Sidiyasa, Whitmore \& Whitmore TCW 3572: 1 - Smythies, Wood \& Ashton 5907: 2 - Soehanda \& Ilham 21: 1 - Sosrodihardjo 40: 1 - Sow 75999: 2.

Takeuchi 6699: 1 - Taylor 2745B: 1 - Tetelepta 19: 1 - Thorenaar 32.T1.P36 (20 Sept. 1920): 3 .

Van Balgooy 4999: 1; 6870: 1 - Van Dijk 348: 1 - Van Eechoud 13: 1 - Van Niel 4043: 2; 4051: 2; 4353: 2 - Van Royen 3125: 1; 3829: 1; 3989: 1; 4984: 1.

Yates 1087: 5.

Zwaan 32.T1.P36 (Aug. 1920): 3. 